International Journal of Instruction

e-ISSN: 1308-1470 • www.e-iji.net
July $2019 \bullet$ Vol.12, No.3

p-ISSN: 1694-609X

pp. $541-560$

Received: 28/10/2018

Revision: 15/04/2019

Accepted: 19/04/2019

OnlineFirst:12/05/2019

\title{
Development of a Definition Maps-Based Plane Geometry Module to Improve the Student Teachers' Mathematical Reasoning Ability
}

\section{Risnawati}

State Islamic University of Riau, Indonesia, risnawati@ uin-suska.ac.id

Dedek Andrian

Corresponding author, Riau Islamic University, Indonesia, dedek.andri321@gmail.com

\section{Memen Permata Azmi}

State Islamic University of Riau, Indonesia, memen.permata.azmi@uin-suska.ac.id

\section{Zubaidah Amir}

State Islamic University of Riau, Indonesia, zubaidah.amir@uin-suska.ac.id

\section{Erdawati Nurdin}

State Islamic University of Riau, Indonesia, erdawati.nurdin@uin-suska.ac.id

This research aimed to develop a definition maps-based plane geometry module to improve the student teachers' mathematical reasoning skills based on the level of Van Hiele. This development research was to produce a product in the form of a module at the college level. This research referred to the ADDIE model involving five stages, i.e. analyze, design, develop, implement, and evaluate. The instruments for data collection were observation sheet, Focus Group Discussion (FGD), assessment sheets, questionnaires, and test. The collected data then were analyzed usingAiken's validity, descriptive and inferential statistical analysis. The questionnaire instrument developed for student teachers was in a good category. The instrument used to test the effectiveness of the module was in a good category. A definition maps-based plane geometry module was in the criteria of feasible, practical and effective. The module was significantly developed in improving mathematical reasoning skills to rigor level.

Keywords: module development, plane geometry, mathematical reasoning, geometry, maps-based plane geometry module

\section{INTRODUCTION}

Geometry is one of the branches of mathematics covered in the school mathematics curriculum. In Indonesia, geometry is basic to middle-level mathematics learning

Citation: Risnawati, Andrian, D., Azmi, M. P., Amir, Z., \& Nurdin, E. (2019). Development of a Definition Maps-Based Plane Geometry Module to Improve the Student Teachers' Mathematical Reasoning Ability. International Journal of Instruction, 12(3), 541-560. https://doi.org/10.29333/iji.2019.12333a 
material. As it is close to humans and around humans, geometry learning allows students to solve problems in everyday life (Abdullah \& Leow, 2017). Geometry has also been studied in the animal world where animals learn various forms from the arena or their area of activity (Miller \& Shettleworth, 2008). This is done with the ability of the complexity to get information around their environment (Prados, 2011). Geometric learning which is based on the environment is a basic rule that can be applied widely in the paradigm of learning (Kosaki, Austen, \& McGregor, 2013).

One of the goals of geometric learning in schools is to provide a systematic attitude and habits for students about the relationships between geometrical structures and classifications between the shapes. The purpose of geometry learning is to develop the ability for thinking logically, developing spatial intuitions, instilling knowledge in learning mathematics for the next level, and interpret arguments mathematically (Grouws, 1992). Geometry learning allows students to apply the knowledge they learn through the topic of geometry to solve problems of everyday life (Kutluca, 2013). Students who have geometrical abilities such as spatial and reasoning ability can enhance or influence mathematical learning on other topics because geometry learning can develop students' cognitive (Battista, Wheatley, \& Talsma, 1982). Therefore, prospective mathematics teachers are required to be able to present complete and comprehensive geometric material to the aspects of relationships and classification of geometry. Thus, geometry material can be delivered in a complete and comprehensive manner to students.

$\operatorname{NCTM}(2000)$ stated that in general the geometric abilities that students must possess are analyzing the character and nature of geometric shapes, constructing mathematical arguments about the relationship of geometry with others, determining the position of a point more specific, transforming and using it symmetrically to analyze mathematical situations, using visualization and spatial reasoning, and applying geometry models to solve mathematical problems. Bishop (1983) stated the reason why geometry needs to be taught in schools because the world is constructed by form and space. Geometry learning highlights the importance of exploring mathematical formulas and oral explanations, which helps in the development of mathematical concepts and critical thinking (Bhagat \& Chang, 2015). Geometry learning can improve students' mathematical abilities specifically reasoning and spatial abilities (Pittalis \& Christou, 2010)

The reasoning is one of the most important and necessary skills in learning geometry. Lee, Stiff, and Curcio(1999) stated that reasoning is the foundation in understanding, working on mathematics and is a tool for understanding abstraction. Mueller and Maher(2009) stated that reasoning forms the basis of mathematical understanding. Torregrosa and Quesada(2008) stated that reasoning is the process of bringing down new information from previous information that already exists, possibly from the problem itself or from previous knowledge. Copi(1978) revealed that reasoning is a specific type of thinking and relates to taking conclusions drawn from existing premises. Reasoning activity is needed in mathematics because mathematics is an abstract science or an abstract domain that requires high-level reasoning to understand it (Staub \& Stern, 
1997). Mathematical understanding is often claimed based on students' reasoning abilities. In other words, students' learning achievement is largely determined by students' reasoning abilities (Nunes et al., 2007). Geometry thinking includes three activities, namely visualization activities, construction activities, and reasoning activities (Jones, 1998).

Students often find geometric concepts as abstract and difficult to understand so that this problem can produce poor performance and reduce students' interest in learning geometry (Vitasari, Wahab, Othman, Herawan, \& Sinnadurai, 2010). Students' geometry learning is lower than other types of mathematics in Turkey (Mullis et al., 2000). Indications of low geometry reasoning ability were also revealed by the results of the research of Özerem (2012). The result showed there were students' difficulties in Cyprus in learning geometry, namely determining the angles on two parallel lines cut by other lines, visualizing, formally reasoning, constructing geometry, and distinguishing vocabulary, terms or definitions in geometry. Teachers and students made misconceptions in understanding geometry (Kuzniak \& Rauscher, 2011). Geometry involves theorems that require skills that are difficult to learn (Wong, Yin, Yang, \&Cheng, 2011). Geometry learning requires hard effort to understand so that educational media needs to be developed.

The findings through observations made over five years during the geometry teaching activities of students of Mathematics Education at the State Islamic University of Riau Province, Indonesia, showed that student teachers had difficulties in learning geometry. Most students teachers were not able to find linkages among square, rectangular, rhombus, parallelogram, kite, and trapezoid. These results indicated the low geometry reasoning ability of student teachers in finding patterns and relationships of the six quadrilateral types. It was easier for the student teachers to complete a quadrilateral type calculation than to understand mathematical concepts and reasoning. Quadrilateral type calculations are presented in school mathematics textbooks. In addition, school mathematics textbooks on geometries only present few construction and visualization activities so that the materials do not support students to reason well. In general, a quadrilateral type material in school mathematics textbooks, as well as in the activity sheets or module rarely discusses the interrelationship of definitions of quadrilateral types. In addition, the definitions of various quadrilateral types presented in textbooks have not given stimuli to student teachers to find a quadrilateral link. The ability level of the geometry of the Islamic State University of Riau Province student teachers is still at the level of analysis of the Van Hiele thinking level.

Based on the reasons above, the development of learning media in the form of a module is important to improve the student teachers' geometry up to level 5, namely Visualization, Analysis, Abstraction, Deduction, and Rigor (Hiele, 2000; Mason, 1998; Vojkuvkova, 2012). It is important to develop research on defining and classifying because the definition of quadrilateral types can affect the classification of other quadrilateral types. In addition, defining quadrilateral types can influence the formulation model of other quadrilateral area calculations. Media development in the form of the module needs to be done because of the lack of printed learning resources 
that discuss in detail the definition and classification of quadrilateral types in Indonesia. In addition, the module is one form of learning material that is arranged systematically, detailedly, interestingly and clearly and it can be used independently, whenever and wherever according to needs. With this module the student teachers are guided to learn the quadrilateral type starting from the definition, translating through pictorial representations, then looking for linkages and classifying quadrilaterals types in the form of definition maps.

\section{METHOD}

This research is development research to produce a product in the form of a module based on defining and classifying quadrilateral at the level of higher education. This development research refers to the ADDIE model (Grafinger, 1988). The ADDIE research model is one of the research design models that can be used in developing complete learning products with stages that are simple and easy to learn (Asad, Razali, \& Sherwani, 2014). The steps of module development using the ADDIE model include five stages, namely analyze, design, develop, implement, and evaluate. The steps to developing this product are more rational and more complete. Therefore, this model can be used for various forms of product development such as models, learning strategies, learning methods, media, and teaching materials.

\section{The Sample and Sample Technique}

The sample in this research was 97 student teachers of the 6th-semester majoring mathematics education. The reason for choosing the 6th-semester student teachers for the study was the 6th semester the student teachers took geometry courses in accordance with the semester credit system regulations set by the State Islamic University of Riau Province. The sampling technique used in this study was purposive sampling where the researcher took all sample suited the research objectives in accordance with the size needed in the research.

\section{The Research Instrument, Validity, and Reliability}

The instruments used in this development research were OS (observation sheets), VAS (validity assessment sheets), PPAS (product practicality assessment sheets), questionnaire, and test. The OS used for observing students activities in using the module. The VAS used to get information from experts and practitioners about the validity of the module was developed by the researcher. The PPAS used to get information from experts, practitioners, and students about the practicality of the module. The questionnaire used to get information about students opinion about the quality of the module. The test used to get information about student ability in mathematical reasoning after using module has developed by the researcher. The validity of the instrument in the study used expert judgment and was analyzed using Aiken validity. The results show all items have had value more 0.4 with valid category (Heri Retnawati, 2015). The reliability of the instrument used Cronbach's Alpha index. The Result shows instruments have Cronbach's Alpha index more 0.7. Based on the validity and reliability can be concluded that the instrument can be used in getting good information about module validity and reliability. 


\section{The Data Analysis Technique}

Data analysis in this research consists of module feasibility, validity, and reliability of the instrument, the practicality of module, and the effectiveness of the module developed. The module feasibility analysis was supported by an acceptable level of feasibility. Analysis of the validity and reliability of the instrument was used to see how valid and reliable the instruments have developed. The product feasibility analysis used expert judgment and was analyzed using descriptive statistics with the validity criteria of 1.00 to1.75 with an invalid/inappropriate category of 1.76 to 2.50 with a fairly valid/quite feasible category of 2.51 to 3.25 with valid/feasible category and 3.25 to 4.00 with a very valid/very feasible category (Sultan, Rofiuddin, Nurhadi, \& Priyatni, 2017). The validity of the questionnaire instruments and test used expert judgment and was analyzed using Aiken's validity, while the reliability used Cronbach's Alpha. The practicality of the module was analyzed using quantitative descriptive by finding the mean and standard deviation of experts, practitioners and student teachers. The results of the practicality analysis of the product were converted using criteria; 1.00 to 1.75 for the impractical category, 1.76 to 2.50 for a fairly practical category, 2.51 to 3.25 for a practical category and 3.25 to 4.00 for a very practical category. The analysis of model effectiveness data was carried out by quantitative descriptive and Independent-Sample $\mathrm{T}$-Test which began with checking normality and homogeneity.

\section{FINDINGS}

\section{General Background}

The first stage, the analyze stage, in this development research was based on multi-time studies or longitudinal research with survey and observation techniques. Longitudinal research was carried out for five years by observing the difficulties of students in understanding the subjects taught in the mathematics education department. Calculus, Trigonometry, Geometry, Algebra, Real Analysis, Numerical Methods, and Linear Programs. From the observation results, it was revealed that the subject the student teachers felt difficult was geometry, and specifically about defining and classifying quadrilateral types. From the five-year observation, the low geometry reasoning ability of student teachers included finding patterns and connecting the six types of the quadrilateral. The observation of geometry ability was based on geometry ability proposed by Van Hiele consisting of visualization, analysis, abstraction, deduction, and rigor. The five-year observation was carried out by giving geometry questions consisting of 2 questions for the level of visualization, 2 questions for analysis, 2 questions for abstraction, 2 questions for deduction, and 2 questions for rigor. From the results of the observation, it was obtained that most of the student teachers were not able to answer the 10 questions. Most of the student teachers' ability was only up to the level of analysis. A summary of students' difficulties in defining and classifying rectangles can be seen in Table 1 . 
Table 1

Observation Results of Student Teachers' Geometry Ability for 5 Years

\begin{tabular}{|c|c|c|c|c|c|c|c|c|c|c|c|}
\hline \multirow{3}{*}{$\begin{array}{l}\text { Van } \\
\text { Hiele } \\
\text { Level }\end{array}$} & \multirow{3}{*}{$\begin{array}{l}\text { Ite } \\
\text { ms }\end{array}$} & \multicolumn{2}{|c|}{ The year 2013} & \multicolumn{2}{|c|}{ The year 2014} & \multicolumn{2}{|c|}{ The year 2015} & \multicolumn{2}{|c|}{ The year 2016} & \multicolumn{2}{|c|}{ The year 2017} \\
\hline & & $\mathrm{CA}$ & $\mathrm{CR}$ & $\mathrm{CA}$ & $\mathrm{CR}$ & $\mathrm{CA}$ & $\mathrm{CR}$ & $\mathrm{CA}$ & $\mathrm{CR}$ & $\mathrm{CA}$ & $\mathrm{CR}$ \\
\hline & & $(\%)$ & $(\%)$ & $(\%)$ & $(\%)$ & $(\%)$ & $(\%)$ & $(\%)$ & $(\%)$ & $(\%)$ & $(\%)$ \\
\hline \multirow{2}{*}{$\begin{array}{l}\text { Visualiza } \\
\text { tion }\end{array}$} & 1 & 50.5 & 50.0 & 56.8 & 55.6 & 66.1 & 58.9 & 68.4 & 64.2 & 72.2 & 65.6 \\
\hline & 2 & 55.7 & 55.7 & 60. & 59.3 & 60.0 & 60.0 & 70.8 & 69.2 & 57.8 & 57.8 \\
\hline \multirow{2}{*}{ Analysis } & 3 & 42.4 & 39.5 & 62.2 & 58.9 & 56.1 & 56.1 & 59.2 & 59.2 & 54.4 & 48.9 \\
\hline & 4 & 48.1 & 44.8 & 59.6 & 59.6 & 58.9 & 58.9 & 58.3 & 55.0 & 60.0 & 56.7 \\
\hline \multirow{2}{*}{$\begin{array}{l}\text { Abstracti } \\
\text { on }\end{array}$} & 5 & 18.7 & 18.6 & 23.7 & 22.6 & 28.3 & 28.3 & 30.0 & 25.8 & 23.3 & 22.2 \\
\hline & 6 & 20.0 & 20.0 & 20.7 & 20.7 & 23.3 & 23.3 & 26.6 & 26.7 & 27.8 & 26.7 \\
\hline \multirow{2}{*}{$\begin{array}{l}\text { Deductio } \\
\mathrm{n}\end{array}$} & 7 & 12.9 & 12.4 & 17. & 16.3 & 18.3 & 16.7 & 14.2 & 13.3 & 22.2 & 22.2 \\
\hline & 8 & 11.0 & 11.0 & 18.2 & 18.2 & 20.6 & 20.6 & 19.2 & 19.2 & 17.8 & 14.4 \\
\hline \multirow{2}{*}{ Rigor } & 9 & 9.1 & 8.1 & 8.1 & 7.4 & 10.0 & 9.4 & 11.7 & 11.6 & 10.0 & 10.0 \\
\hline & 10 & 2.38 & 2.38 & 4.81 & 4.81 & 6.11 & 6.11 & 9.17 & 9.17 & 5.56 & 4.44 \\
\hline \multirow[t]{3}{*}{ N Sample } & & \multirow{3}{*}{\multicolumn{2}{|c|}{$\begin{array}{l}210 \text { of } \\
\text { Student } \\
\text { Teachers }\end{array}$}} & \multirow{3}{*}{\multicolumn{2}{|c|}{$\begin{array}{l}270 \text { of } \\
\text { Student } \\
\text { Teachers }\end{array}$}} & \multirow{3}{*}{\multicolumn{2}{|c|}{$\begin{array}{l}180 \text { of } \\
\text { Student } \\
\text { Teachers }\end{array}$}} & \multirow{3}{*}{\multicolumn{2}{|c|}{$\begin{array}{l}120 \text { of } \\
\text { Student } \\
\text { Teachers }\end{array}$}} & \multirow{3}{*}{\multicolumn{2}{|c|}{$\begin{array}{l}90 \text { of Student } \\
\text { Teachers }\end{array}$}} \\
\hline & & & & & & & & & & & \\
\hline & & & & & & & & & & & \\
\hline
\end{tabular}

Information:

CA: Correct Answer

CR: Correct Reason

Based on these results it can be concluded that the student teachers from 2013 to 2017 were able to answer correctly more than $50 \%$ at the level of visualization and analysis. In addition, the student teachers were able to answer only about $30 \%$ of the level of abstraction, $22 \%$ of the deduction level, and $11 \%$ of the rigor level. The results showed that the student teachers did not understand the definition well and did not classify well the various types of quadrilateral at the level of abstraction, deduction, and rigor. This result was a serious problem for student teachers as they will transfer knowledge to their students in elementary, junior, and senior high schools after they have completed their study at the State Islamic University of Riau Province.

The observations during five years were conducted by detecting students' difficulties in learning through FGD (Focus Group Discussion) with six mathematics lecturers teaching Geometry. The FGD was conducted to discuss the researchers' findings of the difficulties of the student teachers in learning Geometry. From the results of the FGD, six lecturers agreed with the research findings that the student teachers had difficulties in learning geometry specifically in defining, connecting and classifying the quadrilateral types. From the FGD, the researchers offered a solution to make a media in the form of a module to help the student teachers to understand, define, and classify quadrilateral types. The module was very important to develop because it was based on the problems found during learning. The media in the form of geometry textbooks that the student teachers used did not help the student teachers achieve the learning objectives covering drawing conclusions about defining and classifying various types of the quadrilateral. The second stage, the design stage, was to design module to be attractive, to determine the competencies to be achieved, and to determine the problems related to the concept 
of defining and classifying quadrilateral. In the design stage, a module design was produced consisting of three parts, namely introduction, content, and closing.

The third stage is the development stage. The researcher developed the module validity or feasibility assessment sheets, practicality sheets, questionnaires and test to assess the effectiveness of the module. The validity or feasibility assessment module was used to identify the level of validity and feasibility of the module developed. Practicality assessment sheets were used to see how far the module was practically developed in aspects of being easy to use, easy to understand, interesting to use in learning and able to accelerate understanding in Geometry learning. The questionnaire was developed to obtain information about student teachers' opinions about the practicality of the module being developed. The test aimed to check the student teachers' mathematical reasoning ability after participating in learning using the module.

The fourth stage is the implementation stage. The implementation stage was the stage of testing the module. The implementation stage aimed to identify the level of validity of the module. This validation was carried out by the experts on measurement, the experts on mathematical material and the experts on mathematics learning media as well as the practitioners (the lecturers). The validated aspects included module feasibility in terms of material and media design. Material validation and media design aimed to test the feasibility of the content, feasibility of presentation, language assessment, and learning assessment. Validation of student response questionnaires aimed to check the questionnaire format, the language used, and the questionnaire statement to assess the module. Test validation aimed to check the suitability of the problem with mathematical reasoning ability. The next stage of the implementation is testing the practicality level of the module. Practicality test aimed to see the use of a module that were practical to use, easy to understand, interesting to use, useful and able to accelerate the student teachers in understanding geometry. Practical tests were carried out through the assessment of experts, practitioners and teacher candidates. The module effectiveness trial aimed to check the differences in mathematical reasoning skills between student teachers who took part in learning by using a quadrilateral definition and classification module with the students who did not use the module. The module effectiveness test on students' mathematical reasoning ability was done by giving treatments to one class and another class with the condition that both classes were homogeneous. Mathematical reasoning ability in two classes were compared based on the scores obtained at the end of the quadrilateral type learning. Fifth, the evaluate stage was the stage of evaluating the effectiveness of the module that had been developed.

\section{Description of Module}

The quadrilateral types definition and classification module consist of three parts, namely the introduction, content, and closing. The introductory section consists of cover, preface, table of contents, competency standards (achievement of graduate learning), the final ability of each stage of learning, checking the readiness of students regarding prerequisite material, and key answers. The material content section consists of various quadrilateral wide problem presentations that can be done using formulas, elaboration of the material along with the student activity sheets on the definition of 
various quadrilateral types, and an evaluation consisting of four issues regarding the classification of different types of quadrilateral, namely developing the ability to think logically, developing spatial intuition, instilling knowledge of further level of mathematics, and interpreting arguments mathematically. The closing section of the module consists of conclusions, exercises on mathematical reasoning, key answers to various problems, student assessment sheets, and reference lists.

\section{Assessment of Module Feasibility}

An assessment of the feasibility of the module was carried out to see how far the module developed was suitable for the mathematics student teachers. Feasibility of the module was the main point to be assessed. The feasibility of the module was assessed from the aspects of the material used in the module, the competencies expected to be mastered by the student teachers, and the feasibility of the language used to develop the module. The feasibility of the module was assessed by 3 experts (measurement experts, mathematics learning experts, learning media experts) and 4 practitioners (mathematics lecturers). The results of the expert assessment can be seen in Table 2.

Table 2

Results of Module Feasibility Assessment

\begin{tabular}{|c|c|c|c|c|c|c|c|}
\hline \multirow[t]{2}{*}{ Aspect Validated } & \multicolumn{2}{|c|}{$\begin{array}{l}\text { Expert } \\
\text { Average }\end{array}$} & \multicolumn{2}{|c|}{$\begin{array}{l}\text { Practitioner } \\
\text { Average }\end{array}$} & \multicolumn{2}{|c|}{$\begin{array}{l}\text { Total } \\
\text { Average }\end{array}$} & \multirow[t]{2}{*}{ Criteria } \\
\hline & $\bar{\mu}$ & SD & $\mu$ & SD & $\mu$ & SD & \\
\hline $\begin{array}{l}\text { The module developed is in accordance with the } \\
\text { problems that will be resolved. }\end{array}$ & 3.67 & 0.58 & 4.00 & 0.00 & 3.83 & 0.29 & Very Feasible \\
\hline $\begin{array}{l}\text { The material developed in the module is in } \\
\text { accordance with competencies taught }\end{array}$ & 3.33 & 0.58 & 4.00 & 0.00 & 3.67 & 0.29 & Very Feasible \\
\hline $\begin{array}{l}\text { The material developed in the module is in } \\
\text { accordance with the level of education }\end{array}$ & 4.00 & 0.00 & 4.00 & 0.00 & 4.00 & 0.00 & Very Feasible \\
\hline $\begin{array}{l}\text { The module uses punctuation marks, command } \\
\text { marks and clear question words }\end{array}$ & 3.67 & 0.58 & 3.67 & 0.58 & 3.67 & 0.58 & Very Feasible \\
\hline $\begin{array}{l}\text { There are clear instructions on how to work on } \\
\text { the test items on the module }\end{array}$ & 3.67 & 0.58 & 3.67 & 0.58 & 3.67 & 0.58 & Very Feasible \\
\hline $\begin{array}{l}\text { Tables, pictures, graphs, maps are clearly } \\
\text { presented in the module }\end{array}$ & 3.67 & 0.58 & 3.00 & 0.00 & 3.33 & 0.29 & Very Feasible \\
\hline $\begin{array}{l}\text { The formulation of the sentence on the test items } \\
\text { in the module is communicative }\end{array}$ & 3.33 & 0.58 & 3.00 & 0.00 & 3.17 & 0.29 & Feasible \\
\hline $\begin{array}{l}\text { The module uses a standard language and easy to } \\
\text { use }\end{array}$ & 3.67 & 0.58 & 3.67 & 0.58 & 3.67 & 0.58 & Very Feasible \\
\hline $\begin{array}{l}\text { The module does not use words/expressions that } \\
\text { give rise to multiple interpretations and causes } \\
\text { the user to misinterpret }\end{array}$ & 3.33 & 0.58 & 3.67 & 0.58 & 3.50 & 0.58 & Very Feasible \\
\hline The module does not use the language area & 4.00 & 0.00 & 4.00 & 0.00 & 4.00 & 0.00 & Very Feasible \\
\hline
\end{tabular}

Based on the assessment of experts and practitioners it was found that all aspects of the feasibility of the module were assessed with a feasible category ( 1 with a feasible category and 9 with a very feasible category). These results indicated that the experts and practitioners considered the module developed by the researchers was in the appropriate category to be used for mathematics student teachers. The experts and the practitioners assessed the module developed to improve the student teachers' reasoning. 


\section{Aiken validity for the Student Teachers Questionnaire}

Content validity was assessed by three experts, namely two measurement experts and one mathematical learning expert. Content validity was used to see how far the items developed by the researchers in terms of material, design, and language were feasible. The assessment was to obtain information about the opinions of student teachers on the module developed. The results of Aiken validity can be seen in Table 3 .

Table 3

The Result of Aiken validity for the Student Teachers Questionnaire

\begin{tabular}{llllllllll}
\hline Item & Expert & Expert & Expert & $\mathrm{S}$ & $\mathrm{S}$ & $\mathrm{S}$ & $\sum \mathrm{S}$ & Coefficient & Criteria \\
\hline 1 & 4 & 4 & 4 & 3 & 3 & 3 & 9 & 1 & High \\
2 & 4 & 3 & 4 & 3 & 2 & 3 & 8 & 0.889 & High \\
3 & 4 & 4 & 4 & 3 & 3 & 3 & 9 & 1 & High \\
4 & 3 & 3 & 4 & 2 & 2 & 3 & 7 & 0.778 & Moderate \\
5 & 3 & 4 & 4 & 2 & 3 & 3 & 8 & 0.889 & High \\
6 & 3 & 4 & 4 & 2 & 3 & 3 & 8 & 0.889 & High \\
7 & 3 & 3 & 3 & 2 & 2 & 2 & 6 & 0.667 & Moderate \\
8 & 3 & 4 & 4 & 2 & 3 & 3 & 8 & 0.889 & High \\
9 & 3 & 3 & 4 & 2 & 2 & 3 & 7 & 0.778 & Moderate \\
10 & 4 & 3 & 4 & 3 & 2 & 3 & 8 & 0.889 & High \\
11 & 4 & 4 & 4 & 3 & 3 & 3 & 9 & 1 & High \\
12 & 4 & 4 & 4 & 3 & 3 & 3 & 9 & 1 & High \\
\hline \multicolumn{7}{l}{ Reliability of Cronbach Alpha } \\
\hline \multicolumn{7}{l}{}
\end{tabular}

Based on the table above it was obtained the Aiken validity coefficient value from 12 items developed. From the results of the analysis, it was obtained that 9 items had coefficients of more than 0.8 with high categories meaning the items could be used without revision while 3 items had a validity coefficient of Aiken between 0.4 and 0.8 with moderate categories meaning the items could be used with revisions. The items with the moderate or valid category with revisions were due to the language use which was not in accordance with the good and correct Indonesian language.

\section{The validity of the Test to Assess Module Effectiveness}

The test developed to assess the effectiveness of the module needed to be validated by experts to see how far the test items developed were in accordance with the module material, competency standards, and good quality language. The developed test was validated by measurement experts, mathematics learning experts, instructional media experts, and lecturers who taught Geometry subjects. The results of expert validation were calculated by the Aiken validity formula. The result of the analysis can be seen in Table 4. 
Table 4

The Result of Aiken Validity Analysis of Test

\begin{tabular}{lllllllllllllll}
\hline Items & Ex & Ex & Ex & Le & Le & S & S & S & S & S & $\sum S$ & Validity & Criteria \\
\hline 1 & 3 & 3 & 4 & 3 & 3 & 2 & 2 & 3 & 2 & 2 & 7 & 0.7778 & Moderate \\
2 & 3 & 3 & 4 & 3 & 4 & 2 & 2 & 3 & 2 & 3 & 7 & 0.7778 & Moderate \\
3 & 4 & 4 & 3 & 3 & 4 & 3 & 3 & 2 & 2 & 3 & 8 & 0.8889 & High \\
4 & 3 & 4 & 4 & 3 & 4 & 2 & 3 & 3 & 2 & 3 & 8 & 0.8889 & High \\
5 & 3 & 4 & 3 & 3 & 4 & 2 & 3 & 2 & 2 & 3 & 7 & 0.7778 & Moderate \\
6 & 3 & 3 & 4 & 3 & 3 & 2 & 2 & 3 & 2 & 2 & 7 & 0.7778 & Moderate \\
7 & 4 & 3 & 4 & 3 & 4 & 3 & 2 & 3 & 2 & 3 & 8 & 0.8889 & High \\
8 & 4 & 3 & 3 & 3 & 3 & 3 & 2 & 2 & 2 & 2 & 7 & 0.7778 & Moderate \\
9 & 3 & 4 & 3 & 3 & 3 & 2 & 3 & 2 & 2 & 2 & 7 & 0.7778 & Moderate \\
10 & 3 & 4 & 4 & 3 & 4 & 2 & 3 & 3 & 2 & 3 & 8 & 0.8889 & High \\
\hline \multicolumn{10}{l}{ Reliability of Cronbach Alpha } \\
\hline \multicolumn{10}{l}{ Informate }
\end{tabular}

Information

Ex: Assessment from expert

Le: Assessment from Lecturer

$\mathrm{S}$ : The score of experts or lecturer minus 1

$\sum \mathrm{S}$ : Total of the score of experts minus 1

Based on the results of the calculation of the Aiken validity coefficient, the assessment results of expert and practitioner (lecturer of mathematics education from the State Islamic University of Riau province) were obtained. From the results of the analysis, there were 4 items with a high category or valid items and could be used without revision, 6 items with moderate categories meaning three items could be used with revisions. The items that were considered valid with revision needed to be revised by the researchers before being used because the items were not in accordance with the proper and correct Indonesian language and contained meanings that were difficult for the student teachers to understand.

\section{Practicality Test of Module}

Practical tests were conducted to see how far the module developed was practically used by student teachers. There were four aspects assessed, namely, module display, presentation of material, module benefits and efficiency. The results of the assessment of the four aspects can be seen in Table 4 .

Table 4

Assessment Results of the Module Practicality

\begin{tabular}{|c|c|c|c|c|c|c|c|c|c|}
\hline \multirow[t]{2}{*}{ Aspect Validated } & \multicolumn{2}{|c|}{$\begin{array}{l}\text { Expert } \\
\text { Average }\end{array}$} & \multicolumn{2}{|c|}{$\begin{array}{l}\text { Practitioner } \\
\text { Average }\end{array}$} & \multicolumn{2}{|c|}{$\begin{array}{l}\text { Student } \\
\text { Average }\end{array}$} & \multicolumn{2}{|c|}{$\begin{array}{l}\text { Total } \\
\text { Average }\end{array}$} & \multirow[t]{2}{*}{ Criteria } \\
\hline & $\mu$ & SD & $\mu$ & SD & $\mu$ & SD & $\mu$ & SD & \\
\hline $\begin{array}{l}\text { Display of the developed } \\
\text { module is interesting } \\
\text { The material presentation is }\end{array}$ & 3.67 & 0.58 & 3.00 & 0.00 & 3.40 & 0.55 & 3.36 & 0.38 & Very Good \\
\hline $\begin{array}{l}\text { very simple and easy to } \\
\text { understand }\end{array}$ & 3.33 & 0.58 & 3.67 & 0.58 & 3.80 & 0.45 & 3.60 & 0.53 & Very Good \\
\hline $\begin{array}{l}\text { The module developed is useful } \\
\text { The module is developed }\end{array}$ & 3.67 & 0.58 & 3.33 & 0.58 & 3.60 & 0.55 & 3.53 & 0.57 & Very Good \\
\hline $\begin{array}{l}\text { efficiently in the time aspect } \\
\text { (students are quick to } \\
\text { understand geometric material) }\end{array}$ & 3.00 & 0.00 & 3.33 & 0.58 & 3.40 & 0.55 & 3.24 & 0.38 & Good \\
\hline
\end{tabular}


Based on Table 4 it can be concluded that experts, lecturers, and student teacher assess that the module developed can facilitate teacher candidates in providing geometry understanding and increase their level of understanding of the plane geometry, namely quadrilateral. This is evidenced by the four aspects considered to be in a very good and good category.

\section{Results of Module Effectiveness Test}

The module effectiveness test on the student teacher mathematical reasoning ability is done by giving test items of mathematical reasoning ability to the class learning using the defining and classifying of the quadrilateral module and the class that does not use the module. The initial step before testing the effectiveness of the module with the Independent-Sample T-Test is to ensure the data of mathematical reasoning ability in the class that uses module (experimental group) and the class that does not use module (control group) are normally distributed. Test for normality using the Shapiro-Wilk (S$\mathrm{W})$ test. Criteria for testing data normality is if the value of Sig. (p-value) $<\alpha(0.05)$ then the data are not normally distributed while if the value is Sig. (p-value) $>\alpha(0.05)$ then the data are normally distributed. The result of the normality test of mathematical reasoning ability is presented in Table 5.

Table 5

The Testing Results of Normality

\begin{tabular}{lllll}
\hline Learning Groups & N & S-W & Sig. & Conclusion \\
\hline Class Uses Module & 30 & 0,958 & 0,283 & normally distributed \\
Class Doesn't Use Module & 30 & 0,954 & 0,216 & normally distributed \\
\hline
\end{tabular}

Based on the results of the normality test in Table 5 it can be seen that the value of sig. Shapiro-Wilk test data on mathematical reasoning ability in both classes is more than 0.05 so it can be concluded that the data on mathematical reasoning ability in both classes are normally distributed.

The next step after normality testing is homogeneity test. The homogeneity test was conducted to see the variance of the data on mathematical reasoning ability in both learning groups (using and not using a module). Homogeneity test using the Levene test. The test criteria for homogeneity test is if the value of Sig (p-value) $<\alpha(0.05)$ then the treatment group (using a module) and the control group (not using a module) are not homogeneous whereas if the sig ( $\mathrm{p}$-value $)>\alpha\left(\begin{array}{ll}0 & 05\end{array}\right)$ the data are homogeneous. A summary of the results of the homogeneity test of mathematical reasoning ability is presented in Table 6.

Table 6

The Result of Homogeneity Test

\begin{tabular}{llll}
\hline Groups & Levene $(\mathrm{F})$ & p-value & Conclusion \\
\hline Class Use Module & 1,309 & 0,257 & Classes are homogeneous \\
\hline Class Doesn't Use Module & & & \\
\hline
\end{tabular}

Based on the homogeneity test results in Table 6 , it can be seen that the value of sig. Levene test on the data of mathematical reasoning ability in both classes is greater than 0.05 , it can be concluded that the data have homogeneous variance. 
Independent-Sample Test is used to see whether there are differences in the control group learning outcomes (not using a module) and treatment groups (learning using module). To use the Independent-Sample T Test statistic, two conditions are needed, the data is a normal distribution and group homogeneity. Based on the normality and homogeneity tests in Tables $5 \& 6$ it can be concluded that the data are normally distributed and the control and treatment groups are homogeneous so that it meets the requirements for statistical analysis using Independent-Sample T-Test. Statistical testing criteria using Independent-Sample T Test that is if the p-value $<\alpha(0.05)$ then there is a difference between treatment and group groups while if the $p$-value $>\alpha=0.05$ there is no difference in the control class and class treatment. Independent-Sample Test statistical results can be seen in Table 7 .

Table7

The Result of Independent-Sample T-Test

\begin{tabular}{lllll}
\hline Learning & $\mathrm{t}$ & $p$-value & Hypothesis & Conclusion \\
\hline $\begin{array}{l}\text { Use Module } \\
\text { Don't Module }\end{array}$ & 20,845 & 0,000 & Rejected & $\begin{array}{l}\text { Learning use module better than } \\
\text { doesn't use the module }\end{array}$ \\
\hline
\end{tabular}

Based on the result of Table 7, it can be seen explicitly the differences in mathematical reasoning ability of student teacher who use a module and who do not use a module. This result is in line with the result of differences in student-teacher' mathematical reasoning ability in both classes as indicated by the $\mathrm{p}$-value of the Independent-Sample $\mathrm{T}$ Test statistic less than 0.05 ( $\mathrm{p}$-value $<0.05$ ). This means that the average mathematical reasoning ability of student-teacher who use module is significantly better than studentteacher who do not use the module. The result shows that the mathematical reasoning ability of student-teacher who learn to use module of the quadrilateral type are better than students who do not use the module. Student-teacher can define and classify geometric learning specifically about quadrilateral after using the module. Studentteacher can define and classify even the right and correct reasons given questions about quadrilateral. the ability of student-teachers who use module increase to the rigor level even though it only reaches $44.14 \%$. These results can be seen in Table 8 .

Table 8

The Result of Student Teacher Ability That Use Module and Doesn't Use Module

\begin{tabular}{|c|c|c|c|c|c|c|c|}
\hline \multirow{3}{*}{$\begin{array}{l}\text { Van Hiele } \\
\text { Level } \\
\text { Thinking of Geometry }\end{array}$} & \multirow{3}{*}{ Item } & \multicolumn{2}{|c|}{ Class Uses Module } & \multirow{3}{*}{$\begin{array}{l}\text { Average of } \\
\text { Correct } \\
\text { Reason } \\
\end{array}$} & \multicolumn{2}{|c|}{ Class Doesn't Use Module } & \multirow{3}{*}{$\begin{array}{l}\text { Average } \\
\text { of Correct } \\
\text { Reason } \\
\end{array}$} \\
\hline & & Correct & Correct & & Correct & Correct & \\
\hline & & Answer & Reason & & Answer & Reason & \\
\hline \multirow{2}{*}{ Visualization } & 1 & 85.29 & 85.29 & \multirow[t]{2}{*}{89.71} & 84.85 & 84.85 & \multirow[t]{2}{*}{81.82} \\
\hline & 2 & 94.12 & 94.12 & & 78.79 & 78.79 & \\
\hline \multirow{2}{*}{ Analysis } & 3 & 76.47 & 76.47 & \multirow[t]{2}{*}{88.24} & 81.82 & 81.82 & \multirow[t]{2}{*}{86.37} \\
\hline & 4 & 100.00 & 91.18 & & 90.91 & 90.91 & \\
\hline \multirow{2}{*}{ Abstraction } & 5 & 88.24 & 88.24 & \multirow[t]{2}{*}{83.83} & 45.45 & 45.45 & \multirow[t]{2}{*}{43.94} \\
\hline & 6 & 79.41 & 79.41 & & 51.52 & 42.42 & \\
\hline \multirow{2}{*}{ Deduction } & 7 & 76.47 & 73.53 & \multirow[t]{2}{*}{72.06} & 33.33 & 33.33 & \multirow[t]{2}{*}{34.85} \\
\hline & 8 & 70.59 & 70.59 & & 36.36 & 36.36 & \\
\hline \multirow[b]{2}{*}{ Rigor } & 9 & 55.88 & 50.00 & \multirow[t]{2}{*}{44.14} & 24.24 & 24.24 & \multirow[t]{2}{*}{12.12} \\
\hline & 10 & 38.24 & 38.24 & & 0.00 & 0.00 & \\
\hline Total of Sample & & 34 & & & 33 & & \\
\hline
\end{tabular}


Based on Table 8 it can be seen clearly that the percentage of the student teachers who answered correctly were greater as the students used a developed module that provided a clear definition of the quadrilateral. The student teachers could easily classify, differentiate, and connect each quadrilateral correctly. They could answer correctly and find it easy to understand the module developed.

\section{DISCUSSION}

Based on the results of the study, the plane geometry module based on the definition map developed was in the criteria of valid/feasible to use, practical and effective. The instrument developed to assess the module was in a valid and reliable category. Valid and reliable instruments can make the ways easier to get information and know the weaknesses of a product, such as a curriculum, learning media, and other educational products (Andrian, Kartowagiran, \& Hadi, 2018; Burton \& Mazerolle, 2011; Wynd, Schmidt, \& Schaefer, 2003). The module developed as one of the media had a high level of efficiency, as well as effective to improve mathematical reasoning skills. In other words, the module was suitable to be used as broad teaching materials for student teachers who had difficulties in connecting, defining and classifying quadrants. Media can be an effective means of achieving effective learning goals (Peppler \& Kafai, 2007). The media must be the concern of all educators so that they are able to adjust learning in various situations to improve learning outcomes (Lee, Lin, \& Robertson, 2012).

The results of expert assessments, practitioners and media student teacher developed were that the module was practical to use, easy to understand, useful for the student teachers and make them easier to understand geometry, define and classify quadrilateral material. Practical media can support learning to be a significant supporter of classroom learning practices (De Freitas \& Griffiths, 2008). Media informally and formally can bridge learning with culture (Greenhow \& Lewin, 2016). Learning media can fulfill different learning styles that can motivate students, increase learning interest, learning outcomes and enable students to interact with their social culture (Berry \& Staub, 2011). Learning media allows learners to be directed to improve their learning outcomes in class (Danielsson \& Wiberg, 2006). The implementation of learning media not only can improve learning in the classroom but also can improve students' skills in using the media.

From the results of effectiveness testing, the results revealed the student teachers' plane geometry reasoning ability. The ability of the student teachers especially in quadrilateral material that used the defining and classifying module of the quadrilateral was better than the ones who did not use the module. The definition and quadrilateral classification module were based on definition maps. The developed module could increase the ability of the students to map quadrilateral definitions and make a conclusion. The media that are developed based on field analysis can make teaching and learning more effective (Neuhauser, 2002). Effective learning media can be a tool for developing valuable educational goals (Jastrow \& Hollinderbaumer, 2004).

Another finding from the result of the module effectiveness test was the module developed the student teachers' geometry reasoning ability. If it is associated with the theory of five stages of geometrical understanding according to Van Hiele (Mason, 
1998; Vojkuvkova, 2012) namely the stage of visualization, analysis, abstraction, deduction, and rigor, then the group of students who use the defining module and quadrilateral classification, in general, have been able to reach the fifth stage. However, the ability of the student teachers who were capable of up to the rigor level was still below 50\%. The student teachers were able to compare, analyze, and make evidence under different geometric systems. The student teachers who did not use defining modules and quadrilateral classifications were generally only able to reach level three, namely abstraction. The abstraction stage is the stage of being able to understand the properties of concepts or geometrical forms and linking concepts with other concepts (Vojkuvkova, 2012). The results of the achievement stage can be different because of different geometry learning experiences. The experience of learning geometry in the form of activities that provide opportunities to explore, discuss, and interact with matter is the single biggest factor in influencing developments in these levels (Walle, 2006).

The proven plane geometry module based on definition maps can be used as teaching materials that make mathematics student teachers able to realize the goals of geometry learning that were fun because students easily understand what they are learning. In addition, through plane geometry modules based on definition maps, it is expected that teacher candidates are able to analyze the characteristics, characteristics of twodimensional geometry, be able to construct mathematical arguments, connect axioms and make conclusions. The ultimate goal of developing the module is to produce competent teacher candidates and provide direct, complete, and comprehensive geometry material to produce students who have attitudes and habits of thinking systematically and reasoning logically.

\section{CONCLUSION}

Based on the results of the study it can be concluded that the Geometry module that was developed to increase the level of the students' understanding of plane Geometry was in the feasible category to use. The module as one of the learning media that was developed was supported by valid and reliable instruments. The module developed had high practical value because it was easy to understand, very useful in the development of education, and accelerated the student teachers' understanding in achieving the level of understanding Geometry and mathematical reasoning. The module developed was effective in providing a holistic understanding to the student teachers about defining, classifying, and linking axioms to the plane Geometry, namely quadrilateral. The level of understanding of the student teachers who used the module developed by the researcher differed significantly from the student teachers who did not use the module. The level of understanding of the student teachers who used module reached the fifth level based on Van Hiele level while the level of understanding of the student teachers who did not use the module was only at the third 1

\section{ACKNOWLEDGMENTS}

Support for this project was funded by Islamic state university of Riau Province. The ideas in this manuscript are solely generated by the authors. We would like to thank everyone who contributed in completing this manuscript. 


\section{REFERENCES}

Abdullah, M. F. N. L., \& Leow, W. (2017). Learning Form One Geometry : Validity and Reliability of a Self-Evaluation. Malaysian Journal of Learning and Instruction, 14(1), 211-265.

Andrian, D., Kartowagiran, B., \& Hadi, S. (2018). The Instrument Development to Evaluate Local Curriculum in Indonesia. International Journal of Instruction, 11(4), 922-934. https://doi.org/10.12973/iji.2016.9115a

Asad, M., Razali, \& Sherwani, F. (2014). Instructional Models For Enhancing The Performance Of Students And Workforce During Educational Training. Academia Arena, 6(3), 285-311.

Battista, M. T., Wheatley, G. H., \& Talsma, G. (1982). The importance of spatial visualization and cognitive development for geometry learning in preservice elementary teachers. Journal for Research in Mathematics Education, 13(5), 332-340. https://doi.org/10.2307/749007

Berry, J., \& Staub, N. (2011). Technology, pedagogy and digital production: a case study of children learning new media skills. Journal of Scholarship and Practice, 8(1), 24-33. https://doi.org/10.1080/17439880701343352

Bhagat, K. K., \& Chang, C. Y. (2015). Incorporating GeoGebra into geometry learningA lesson from India. Eurasia Journal of Mathematics, Science and Technology Education, 11(1), 77-86. https://doi.org/10.12973/eurasia.2015.1307a

Bishop, J. (1983). Space and geometry. Acquisition of mathematics concepts and processes. New York: Academic Press.

Burton, L. J., \& Mazerolle, S. M. (2011). Survey instrument validity part i: principles of survey instrument development and validation in athletic training education research. Journal of Athletic Training Education, 6(1), 27-35.

Copi, I. M. (1978). Introduction to logic. New York: Mcmillan Publishing Co. , Inc.

Danielsson, K., \& Wiberg, C. (2006). Participatory design of learning media: Designing educational computer games with and for teenagers. Interactive Technology \& Smart Education, 3(4), 275-291.

De Freitas, S., \& Griffiths, M. (2008). The convergence of gaming practices with other media forms: What potential for learning? A review of the literature. Learning, Media and Technology, 33(1), 11-20. https://doi.org/10.1080/17439880701868796

Grafinger, D. (1988). Basics of instructional systems development. Alexandria: American Society for Training and Development.

Greenhow, C., \& Lewin, C. (2016). Social media and education: reconceptualizing the boundaries of formal and informal learning. Learning, Media and Technology, 41(1), 630. https://doi.org/10.1080/17439884.2015.1064954 
Grouws, D. . (1992). Handbook of research on mathematics teaching and learning. New York: MacMillan Publisher Company.

Hiele, P. M. Van. (2000). Begin with play. Teaching Children Mathematics, 6(February 1999), 310-316.

Jastrow, H., \& Hollinderbaumer, A. (2004). On the use and value of new media and how medical students assess their effectiveness in learning anatomy. Anatomical Record Part B New Anatomist, 280(1), 20-29. https://doi.org/10.1002/ar.b.20027

Jones, K. (1998). Theoretical frameworks for the learning of geometrical reasoning. Of the British Society for Research into Learning, 18(February), 29-34. Retrieved from http://eprints.soton.ac.uk/41308/

Kosaki, Y., Austen, J. M., \& McGregor, A. (2013). Overshadowing of geometry learning by discrete landmarks in the water maze: Effects of relative salience and relative validity of competing cues. Journal of Experimental Psychology: Animal Behavior Processes, 39(2), 126-139. https://doi.org/10.1037/a0031199

Kutluca, T. (2013). The effect of geometry instruction with dynamic geometry software; GeoGebra on Van Hiele geometry understanding levels of students. Educational Research and Reviews, 8(17), 1509-1518. https://doi.org/10.5897/ERR2013.1554

Kuzniak, A., \& Rauscher, J. C. (2011). How do teachers' approaches to geometric work relate to geometry students' learning difficulties? Educational Studies in Mathematics, 77(1), 129-147. https://doi.org/10.1007/s10649-011-9304-7

Lee, J., Lin, L., \& Robertson, T. (2012). The impact of media multitasking on learning. Learning, Media and Technology, 37(1), 94-104. https://doi.org/10.1080/17439884.2010.537664

Mason, M. (1998). The van Hiele Levels of geometric understanding. The Professional Handbook for Teachers: Geometry: Explorations and Applications, 4, 4-8. Retrieved from http://jwilson.coe.uga.edu/EMAT8990/GEOMETRY/Mason, Marguerite. The van Hiele Levels of Geometric Understanding. 2002.pdf

Miller, N. Y., \& Shettleworth, S. J. (2008). An associative model of geometry learning: a modified choice rule. Journal of Experimental Psychology. Animal Behavior Processes, 34(3), 419-422. https://doi.org/10.1037/0097-7403.34.3.419

Mueller, M., \& Maher, C. (2009). Learning to reason in an inf orn \al math after-school program. Mathematics Education Research Journal, 21(3), 7-35.

Mullis, I. V. S., Martin, M. O., Gonzalez, E. J., Gregory, K. D., Garden, R. A., O'Connor, K. M., ... Smith, T. A. (2000). TIMSS 1999 international mathematics report: Findings from IEA's repeat of the third international mathematics and science study at the eighth grade. https://doi.org/10356/15300

NCTM. (2000). Principles and standards for school mathematics. (NCTM, Ed.). Reston. 
Neuhauser, C. (2002). Learning style and effectiveness of online and face-to-face instruction. American Journal of Distance Education, 16(2), 99-113. https://doi.org/10.1207/S15389286AJDE1602_4

Nunes, T., Bryant, P., Evans, D., Bell, D., Gardner, S., Gardner, A., \& Carraher, J. (2007). The contribution of logical reasoning to the learning of mathematics in primary school. British Journal of Developmental Psychology, 25(1), 147-166. https://doi.org/10.1348/026151006X153127

Özerem, A. (2012). Misconceptions in geometry and suggested solutions for seventh grade students. Procedia - Social and Behavioral Sciences, 55(4), 720-729. https://doi.org/10.1016/j.sbspro.2012.09.557

Peppler, K. A., \& Kafai, Y. B. (2007). From SuperGoo to scratch : Exploring creative digital media production in informal learning. Learning, Media and Technology, 32(2), 149-166. https://doi.org/10.1080/17439880701343337

Pittalis, M., \& Christou, C. (2010). Types of reasoning in 3D geometry thinking and their relation with spatial ability. Educational Studies in Mathematics, 75(2), 191-212. https://doi.org/10.1007/s10649-010-9251-8

Prados, J. (2011). Blocking and overshadowing in human geometry learning. Journal of Experimental Psychology: Animal Behavior Processes, 37(1), 121-126. https://doi.org/10.1037/a0020715

Staub, F. C., \& Stern, E. (1997). Abstract reasoning with mathematical constructs. International Journal of Educational Research, 27(1), 63-75. https://doi.org/10.1016/S0883-0355(97)88444-3

Sultan, Rofiuddin, A., Nurhadi, \& Priyatni, E. T. (2017). The development of a critical reading learning model to promote university students' critical awareness. New Educational Review, 48(2004), 76-86. https://doi.org/10.15804/tner.2017.48.2.06

Torregrosa, G., \& Quesada, H. (2008). The coordination of cognitive processes in solving geometric problems requiring formal proof. Proceedings of the Joint Meeting of PME 32 and PME-NA XXX, 4(October), 321-328.

V, L., Stiff, \& Curcio, F. R. (1999). Developing Mathematical Reasoning in Grades K12. Virginia USA: NCTM.

Vitasari, P., Wahab, M. N. A., Othman, A., Herawan, T., \& Sinnadurai, S. K. (2010). The relationship between study anxiety and academic performance among engineering students. Procedia-Social and Behavioral Sciences, 8, 490-497. https://doi.org/10.1016/j.sbspro.2010.12.067

Vojkuvkova, I. (2012). The van Hiele model of geometric thinking. WDS'12 Proceedings of Contributed Papers, 1, 72-75.

Walle, J. A. . (2006). Matematika Sekolah Dasar dan Menengah. Jakarta: Erlangga.

Wong, W.-K., Yin, S.-K., Yang, H.-H., \& Cheng, Y.-H. (2011). Using computer- 
assisted multiple representations in learning geometry proofs. Educational Technology \& Society, 14(3), 43-54. Retrieved from http://login.ezproxy.lib.umn.edu/login?url=http://search.ebscohost.com/login.aspx?direc $\mathrm{t}=$ true $\&$ AuthType $=$ ip , uid $\& \mathrm{db}=$ eric $\& A N=E J 963223 \&$ site $=$ ehost -

live\%0Ahttp://www.ifets.info/journals/14_3/5.pdf

Wynd, C. A., Schmidt, B., \& Schaefer, M. A. (2003). Two quantitative approaches for estimating content validity. Western Journal of Nursing Research, 25(5), 508-518. https://doi.org/10.1177/0193945903252998

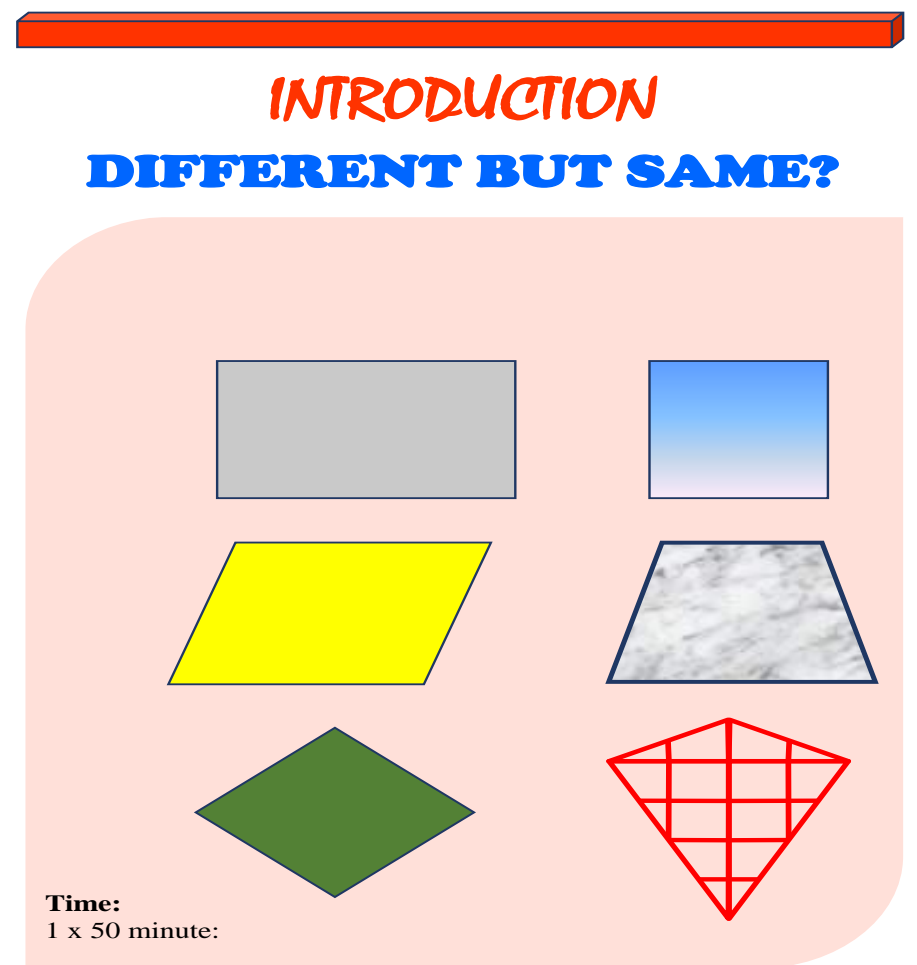

Consider the following problem

At one time Imam \& Isna were given the assignment by the tutor, here is the problem: Determine the area of each build below! 

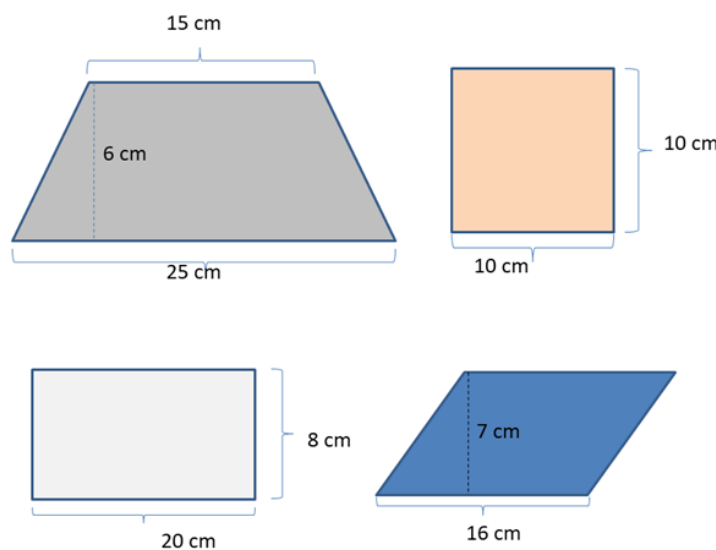

The teacher told them to see the formula in the book from a collection of mathematical formulas. When they arrived at their homes,

\section{Imam:}

Imam immediately opens the book a collection of mathematical formulas, then gets a page about the formula for the area of each one to wake up. After that, the Imam can finish both questions correctly.

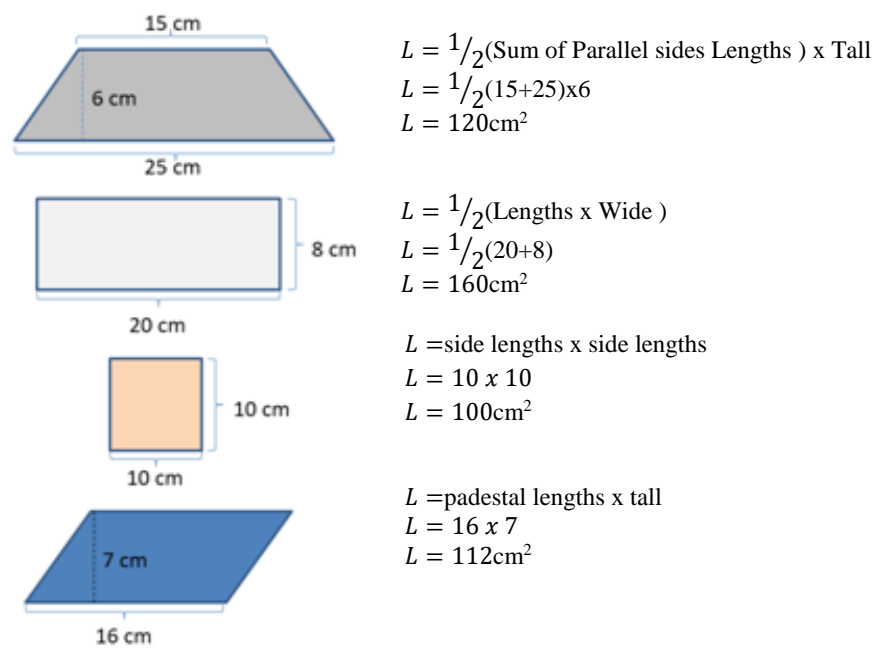

Isna:

On the other hand, after Isna opened the book, he saw many pages in the formula part of the area had been torn so that all that remained was the formula for the area of the 
trapezoidal. In order not to be angered by the teacher, Isna tried to use the formula of the Trapezoid area to determine also the width of the other building areas.

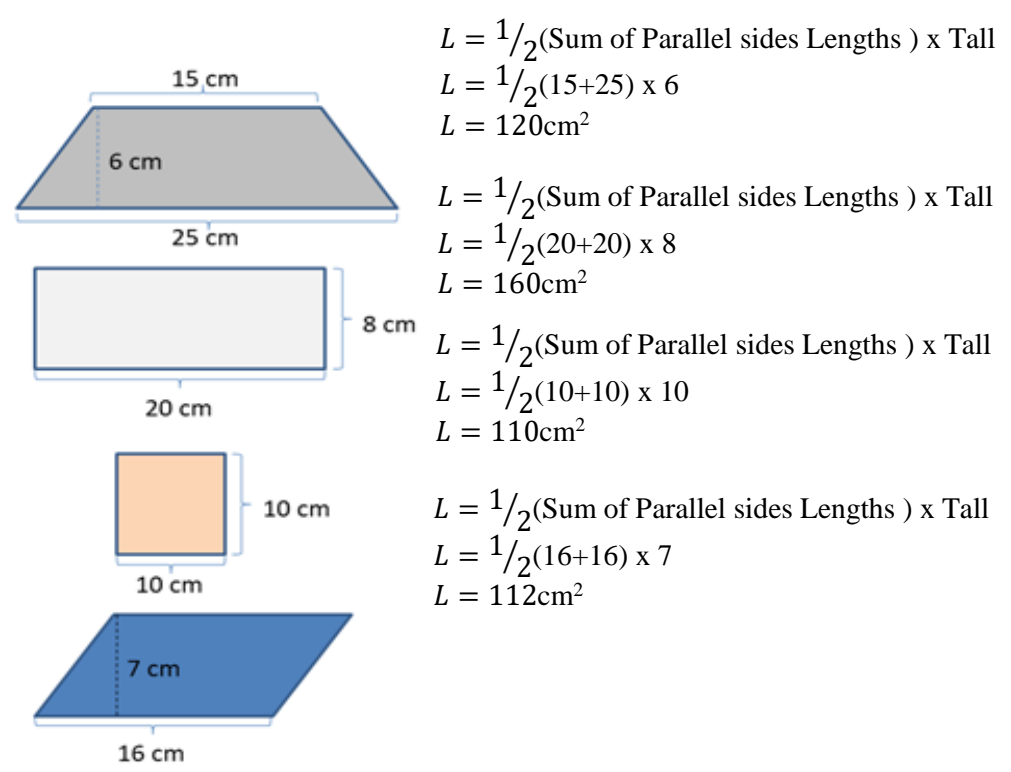

International Journal of Instruction, July $2019 \bullet$ Vol.12, No.3 